\title{
Presence of exposed phospholipids in the outer membrane of Vibrio cholerae
}

\author{
Saptarshi Paul, ${ }^{1}$ Keya Chaudhuri, ${ }^{1}$ Anadi Nath Chatterjee ${ }^{2 *}$ and Jyotirmoy Das ${ }^{1}$ \\ ${ }^{1}$ Biophysics Division, Indian Institute of Chemical Biology, 4 Raja S. C. Mullick Road, Calcutta 700032, India \\ ${ }^{2}$ Biotechnology Programme, Jadavpur University, Jadavpur, Calcutta 700032, India
}

(Received 27 September 1991; revised 28 November 1991; accepted 13 January 1992)

\begin{abstract}
Vibrio cholerae 569B was found to be highly sensitive to a wide range of chemicals, particularly hydrophobic compounds and neutral and anionic detergents. The phospholipid profile of the outer membrane was similar to that reported for other Gram-negative bacteria. The lipopolysaccharide (LPS) contained $O$-antigenic sugars and exhibited heterogeneity. In addition, the LPS moiety was characterized by a relatively low negative charge. Analysis by topological probes revealed the presence of a significant amount of exposed phospholipids in the outer membrane. The reduced negative charge of LPS molecules and the exposed phospholipids present in the outer membrane could be important in the increased permeation of exogenous compounds in $\mathrm{V}$. cholerae.
\end{abstract}

\section{Introduction}

Normally Gram-negative bacteria with smooth-type LPS in the outer membrane are resistant to hydrophobic compounds and detergents (Nikaido \& Vaara, 1985). This resistance is primarily due to the absence of exposed phospholipids in the outer membrane, which restricts the entry of non-polar compounds by diffusion (Nikaido \& Vaara, 1985; Sukupolvi \& Vaara, 1989). In deep rough mutants, and in mutants with deletion of major outermembrane proteins, this structural asymmetry is lost, and exposed phospholipids appear on the cell surface (Lugtenberg \& van Alphen, 1983; Nikaido \& Vaara, 1985). As expected, such mutant strains exhibit higher sensitivity to hydrophobic compounds owing to the increased rate of their permeation across the outer membrane (Nikaido \& Vaara, 1985; Sukupolvi \& Vaara, 1989).

Several studies indicate the atypical nature of the cell surface of Vibrio cholerae 569B. While cholera toxin synthesized by Escherichia coli remained intracellular, the $E$. coli enterotoxin synthesized in $V$. cholerae was excreted (Neill et al., 1983). Furthermore, Vibrio cells are highly sensitive to protein denaturants, and it is possible to isolate outer membranes directly from whole cells by treatment with urea (Lohia et al., 1984). The present paper reports that the sensitivity of $V$. cholerae to a wide variety of chemicals might be due to the presence of

* Author for correspondence. Tel. 724044. exposed phospholipids and the relatively low net negative charge of LPS molecules present in its outer membrane.

\section{Methods}

Organisms and growth conditions. V. cholerae strain 569B and its detergent-resistant mutant, lpa-1 (Paul et al, 1990) were grown in complex media with shaking at $37^{\circ} \mathrm{C}$ as described previously (Lohia et al., 1984). A low phosphate medium was used for the induction of alkaline phosphatase (Roy et al., 1982). Escherichia coli C-600 was grown with shaking at $37^{\circ} \mathrm{C}$ in Luria broth.

Determination of minimum inhibitory concentration (MIC). The MIC of various compounds was determined both by broth dilution and plate assay. For broth dilution assay, about $5 \times 10^{4}$ cells were incubated in growth medium containing different concentrations of the compound, shaken at $37^{\circ} \mathrm{C}$ for $16 \mathrm{~h}$. The lowest concentration of the compound at which there was no visible growth was taken as the MIC. For plate assay, around $300-400$ c.f.u. were spread on nutrient agar containing different concentrations of the test compound. After incubation for $24 \mathrm{~h}$ at $37^{\circ} \mathrm{C}$, the lowest concentration of the compound at which no c.f.u. were observed was taken as the MIC. The results of the two assays were comparable.

Treatment with poly-L-lysine and polymyxin binding. Cells (4-5 $\times 10^{8}$ c.f.u. $\left.\mathrm{ml}^{-1}\right)$ suspended in $10 \mathrm{~mm}$-phosphate buffer $(\mathrm{pH} \mathrm{7.5)}$ were incubated with poly-L-lysine $\left(100 \mu \mathrm{g} \mathrm{ml}^{-1}\right)$ for $30 \mathrm{~min}$ at $37^{\circ} \mathrm{C}$, centrifuged and the supernatant and pellet were assayed for the periplasmic enzyme cyclic phosphodiesterase. To determine the deoxycholate sensitivity of the cationic-peptide-treated cells, the cell pellet was suspended in $70 \mathrm{~mm}$-potassium phosphate buffer ( $\mathrm{pH} \mathrm{7.2)}$ containing $0.05 \%$ deoxycholate, and the $A_{585}$ was recorded after $10 \mathrm{~min}$ at $37^{\circ} \mathrm{C}$. Polymyxin binding to purified LPS was assayed according to Vaara et al. (1981). About $2 \mathrm{mg}$ purified LPS and $1.2 \mathrm{mg}$ 
polymyxin B sulphate were used for each assay. The amount of bound polymyxin was calculated from the number of free amino groups present in the LPS pellet normalized against the number of free amino groups present in the LPS sample not treated with polymyxin B.

Membrane preparation. Isolation of crude cell envelope and its fractionation into outer and inner membrane with $4 \mathrm{M}$-urea for the analysis of phospholipids and LPS, and with $1 \%$ Sarkosyl for the assay of membrane proteins, were carried out as described previously (Lohia et al., 1984, 1985; Filip et al., 1973). The sucrose density gradient centrifugation method for separation of the two membrane systems of Gram-negative bacteria did not work satisfactorily in $V$. cholerae (Lohia et al., 1984). The inner membrane contamination in the outer membranes never exceeded $8 \%$ as detected by the cytochrome assay (Osborn et al., 1972). Contamination by outer membrane in the inner membrane preparation was less than $5 \%$ as estimated by heptose assay (Wright \& Rebers, 1972). Yields of crude cell envelope, and outer and inner membranes were around 14,8 and 6 per cent respectively of the cellular dry weight.

Isolation and analysis of LPS, lipid $A$ and phospholipids. Isolation of LPS from crude cell envelopes, and subsequent separation of the lipid $A$ and polysaccharide moieties were carried out as described previously (Paul et al., 1990). LPS was labelled by growing cells in the presence of $\left[{ }^{14} \mathrm{C}\right.$ ]acetate [specific activity: $56.7 \mathrm{mCi}(2 \cdot 1 \mathrm{GBq}) \mathrm{mmol}^{-1}, 0.2 \mu \mathrm{Ci}$ $\left.(7.4 \mathrm{kBq}) \mathrm{ml}^{-1}\right]$ for 3 generations. Since $\left[{ }^{14} \mathrm{C}\right]$ acetate could also label phospholipids, the radioactive LPS was freed from phospholipids by repeated extraction with chloroform/methanol $(2: 1, v / v)$ till no further counts were extractable. Finally, the labelled LPS was solubilized in Laemmli sample buffer and analysed by $14 \%$ (w/v) SDS-PAGE and fluorography (Ray et al., 1984). Phospholipids were extracted from whole cells and isolated membranes by chloroform/methanol $(2: 1, \mathrm{v} / \mathrm{v})$ and quantitatively analysed after their separation by TLC as described previously (Lohia et al., 1985). The phospholipids were essentially free of LPS, as no 3-hydroxytetradecanoic acid could be detected by GLC (Paul et al., 1990).

CNBr-activated dextran coupling. Preparation of $\mathrm{CNBr}$-activated dextran T-10 (molecular mass $10 \mathrm{kDa}$ ) and its coupling to whole cells were done as described by Kamio \& Nikaido (1976). Cells were labelled by growing them for 3 generations in media containing $\left[2-{ }^{3} \mathrm{H}\right]$ glycerol [specific activity: $1 \mathrm{Ci}(37 \mathrm{GBq}) \mathrm{mmol}^{-1}, 2 \mu \mathrm{Ci}(74 \mathrm{kBq}) \mathrm{ml}^{-1}$ ] followed by suspension and shaking for $30 \mathrm{~min}$ in fresh growth media containing $0.05 \%$ glycerol. The cell suspension in $50 \mathrm{~mm}$-borate buffer (pH 8.5) was divided into two parts, 0.1 M-ethanolamine was added to the control tube at $0 \mathrm{~min}$ and the coupling reaction was initiated in the other tube with freshly prepared CNBr-dextran complex, continued for $1 \mathrm{~h}$ at $25^{\circ} \mathrm{C}$. After termination of the reaction with excess ethanolamine, phospholipids were isolated from both control and experimental cells and separated on TLC plates. In some cases the samples were fractionated into outer and inner membranes prior to phospholipid extraction. The separated phospholipids were visualized by iodine vapour and ninhydrin, and appropriate spots from a parallel lane were scraped into scintillation vials and assayed for radioactivity.

Dansylation of whole cells. Dansyl chloride-cyclodextrin complex (20 mg) prepared following the method of Kinoshita et al. (1974) was added to $10 \mathrm{ml}$ of cells $\left(1.5 \times 10^{9}\right.$ c.f.u. $\left.\mathrm{ml}^{-1}\right)$ suspended in $50 \mathrm{mM}$ borate buffer ( $\mathrm{pH} 8.5$ ) containing $1 \mathrm{mM}-\mathrm{MgCl}_{2}$. After stirring in the dark for $60 \mathrm{~min}$ at room temperature, the unreacted complex was removed by low speed centrifugation $(1000 \mathrm{~g}, 5 \mathrm{~min})$ and the cells were washed repeatedly in the above suspension buffer. Finally, phospholipids from isolated membranes of the treated cells were separated by TLC, visualized and photographed under UV light. All operations were carried out in the dark.
Other methods. Standard methods were used for assay of dye uptake (Wolf-Watz et al., 1975). Free amino groups were assayed by 2,4dinitrofluorobenzene using D-glutamic acid as a standard (Ghuysen \& Strominger, 1963). Glucosamine in lipid A was assayed as described earlier (Paul et al., 1990). Protein was estimated by the method of Markwell et al. (1978). Alkaline phosphatase and cyclic phosphodiesterase were assayed by standard methods using p-nitrophenyl phosphate and bis-p-nitrophenyl phosphate as substrates respectively (Roy et al., 1982; Neu \& Heppel, 1965). Enzyme activity in cell pellet was assayed after sonication for $1 \mathrm{~min}$ at $4^{\circ} \mathrm{C}$.

\section{Results}

\section{Atypical permeability features of the outer membrane}

$V$. cholerae cells were found to be highly sensitive to a wide variety of compounds (Table 1). Since the MIC values may vary with the experimental conditions, the sensitivity of $E$. coli strain C-600 (chemotype Ra) was determined under identical conditions and significant differences between these two strains were observed (Table 1, column ' $b / a$ '). The sensitivity of $V$. cholerae was most marked towards hydrophobic antibiotics like novobiocin and rifampicin and neutral and anionic detergents (Triton X-100 and SDS). One exception to the above was the hydrophobic compound phenol (Table 1). Interestingly, sensitivity of $V$. cholerae towards cationic

Table 1. MIC of various compounds for $V$. cholerae $569 B$ and $E$. coli $C-600$

\begin{tabular}{|c|c|c|c|}
\hline \multirow[b]{2}{*}{ Agent } & \multicolumn{3}{|c|}{ MIC } \\
\hline & $\begin{array}{c}\text { V. cholerae } \\
(a)\end{array}$ & $\begin{array}{c}\text { E. coli } \\
\text { (b) }\end{array}$ & $(b / a)$ \\
\hline \multicolumn{4}{|l|}{ Antibiotics* } \\
\hline Penicillin G & 2 & 20 & 10 \\
\hline Ampicillin & 2 & 5 & 2.5 \\
\hline Tetracycline & 2 & 50 & 25 \\
\hline Chloramphenicol & 5 & 5 & 1.0 \\
\hline Neomycin & 2 & 20 & 10 \\
\hline Novobiocin & 2 & 750 & 375 \\
\hline Rifampicin & $0 \cdot 1$ & 40 & 400 \\
\hline Nalidixic acid & 1 & 25 & 25 \\
\hline Polymyxin B & $0 \cdot 2$ & 0.05 & $0 \cdot 25$ \\
\hline \multicolumn{4}{|l|}{ Detergents } \\
\hline Sodium dodecyl sulphate $\dagger$ & 0.01 & $2 \cdot 0$ & 200 \\
\hline Sodium deoxycholatet & 0.05 & 2.5 & 50 \\
\hline Triton $\mathrm{X}-100+$ & 0.02 & $>5$ & $>250$ \\
\hline Cetyltrimethylammonium bromide* & 20 & 50 & $2 \cdot 5$ \\
\hline \multicolumn{4}{|l|}{ Other compounds } \\
\hline Crystal violet* & 2 & 20 & 10 \\
\hline Phenolt & $0 \cdot 1$ & 0.1 & 1.0 \\
\hline Stearic acid $\ddagger$ & 0.4 & $>10$ & $>25$ \\
\hline Protamine sulphate* & 50 & 50 & $1 \cdot 0$ \\
\hline
\end{tabular}

* MIC in $\mu \mathrm{g} \mathrm{ml} \mathrm{m}^{-1}$.

$+\mathrm{MIC}$ as $\%(w / v)$.

$\ddagger$ MIC as $\mathrm{mM}$. 


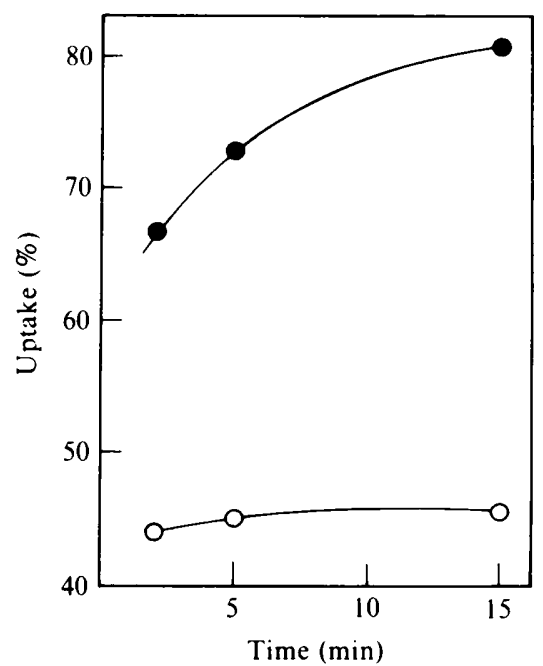

Fig. 1. Uptake of crystal violet by $V$. cholerae $(\bullet)$ and $E$. coli $(O)$. Cells in the exponential phase of growth in NB (about $5 \times 10^{8}$ c.f.u. $\mathrm{ml}^{-1}$ ) were treated with $10 \mu \mathrm{g}$ crystal violet per ml. At different times during growth at $37^{\circ} \mathrm{C}$, samples were withdrawn and the amount of dye in the supernatant was estimated from the absorbance at $590 \mathrm{~nm}$.

agents like cetyltrimethylammonium bromide and protamine sulphate was much less marked and the only compound found so far to which $V$. cholerae was more resistant than $E$. coli was the cationic amphipathic antibiotic polymyxin B $(b / a=0 \cdot 25$, Table 1$)$.

Sensitivity to hydrophobic compounds and detergents suggested that the outer membrane of $V$. cholerae might not be an effective barrier to such compounds. This was confirmed by the extensive lysis (about $80 \%$ ) of these cells following treatment with $0.01 \%$ SDS, sodium deoxycholate and Triton X-100. There was no detectable lysis of $E$. coli cells even at ten times the concentrations of these detergents. When crystal violet was added to $V$. cholerae cells in the exponential phase of growth, the uptake of dye continued during the entire $15 \mathrm{~min}$ of incubation resulting in incorporation of about $80 \%$ of the added dye (Fig. 1). In contrast, uptake of crystal violet in $E$. coli was essentially complete within 2 min of addition of the dye and not more than $45 \%$ of the dye was finally incorporated. The incorporated dye in $V$. cholerae cells was divided almost equally between the cell envelope and the cytoplasm. On the other hand, in E. coli, more than $95 \%$ of the dye was confined to the envelope fraction. This clearly indicated that the $V$. cholerae envelope did not constitute an effective barrier to the entry of crystal violet.

Leakage of periplasmic proteins indicated instability of the outer membrane. We have found that $15-20 \%$ of two periplasmic enzymes, cyclic phosphodiesterase and alkaline phosphatase, were consistently released into the culture medium by exponential phase cells. The unstable nature of the $V$. cholerae cell surface was further
Table 2. Distribution of bound phosphate and free amino groups in LPS of $V$. cholerae and $E$. coli

\begin{tabular}{cccccccc}
\hline \hline & \multicolumn{3}{c}{$V$. cholerae } & & \multicolumn{3}{c}{ E. coli } \\
\cline { 2 - 3 } \cline { 6 - 8 } $\begin{array}{c}\text { Macromolecule } \\
\text { analysed }\end{array}$ & $\begin{array}{c}\mathrm{PO}_{4} \\
(a)\end{array}$ & $-\mathrm{NH}_{2}$ & & & $\mathrm{PO}_{4}$ & $-\mathrm{NH}_{2}$ & \\
& LPS & 0.80 & 0.15 & 5.3 & 1.27 & 0.10 & 12.7 \\
PS $^{*}$ & 0.55 & 0.12 & 4.6 & 0.98 & 0.07 & 14.0 \\
\hline \hline
\end{tabular}

* PS of LPS was obtained after splitting off the lipid A by treatment with $1 \%$ acetic acid at $100{ }^{\circ} \mathrm{C}$ for $2.5 \mathrm{~h}$. Results are expressed as $\mu \mathrm{mol}$ (mg LPS) ${ }^{-1}$

documented by the observation that any perturbation likely to cause cellular damage, such as penicillin treatment, resulted in a rapid release of periplasmic proteins preceding other effects of cell damage, e.g. loss of viability or cellular rigidity. Since divalent cations are known to play a significant role in the repair of outer membrane defects such as enhanced sensitivity to exogenous chemicals and leakage of periplasmic proteins (Stan-Lotter et al., 1979), the leakage of periplasmic proteins and the sensitivity to exogenous compounds were compared in $V$. cholerae grown in the presence and absence of $1 \mathrm{~mm}-\mathrm{MgCl}_{2}$. No significant difference in any of these parameters was observed.

\section{Surface charge}

The fact that $V$. cholerae was relatively resistant to basic compounds (Table 1) prompted us to analyse the distribution of fixed charged groups present in the polysaccharide (PS). The total phosphate and free amino groups in the LPS and PS of $V$. cholerae were estimated and compared with those of $E$. coli cells. The ratio of phosphate to amino groups in the LPS and PS of $E$. coli were 2.4 and 3.0 times higher, respectively, than the corresponding values for $V$. cholerae (Table 2). Furthermore, there was a significant difference in the ability of LPS molecules isolated from $E$. coli and $V$. cholerae to bind the cationic antibiotic polymyxin $B$. The amount of polymyxin $B$ bound expressed as $\mu \mathrm{mol}$ of free amino groups of bound polymyxin per mg LPS was 0.23 for $E$. coli $\mathrm{C}-600$ and $0 \cdot 13$ for $V$. cholerae 569B. Such a low distribution of anionic groups in the outer membrane could be responsible for the ability of poly-L-lysine to destabilize the outer membrane of $V$. cholerae cells. Pretreatment of cells in the exponential phase of growth $\left(5 \times 10^{8}\right.$ c.f.u. $\left.\mathrm{ml}^{-1}\right)$ suspended in $20 \mathrm{~mm}$-phosphate buffer (pH 7.4) with poly-L-lysine $\left(100 \mu \mathrm{g} \mathrm{ml}^{-1}\right)$ for $30 \mathrm{~min}$ at $37^{\circ} \mathrm{C}$ did not sensitize them to deoxycholate induced lysis nor lead to any detectable increase in the release of the periplasmic enzyme cyclic phosphodiesterase. 
Table 3. Composition of outer and inner membrane of $V$. cholerae

Each value is the mean of at least three sets of independent experiments.

\begin{tabular}{|c|c|c|c|c|c|c|c|c|c|c|c|c|c|}
\hline \multirow[b]{2}{*}{ Sample } & \multirow{2}{*}{$\begin{array}{l}\text { Protein } \\
\quad(a)\end{array}$} & \multirow{2}{*}{$\begin{array}{l}\text { LPS } \\
\text { (b) }\end{array}$} & \multirow{2}{*}{$\begin{array}{c}\text { Phospholipid } \\
(c) \\
\left.\text { rane })^{-1}\right]\end{array}$} & \multirow[b]{2}{*}{$a$} & \multirow[b]{2}{*}{ : } & \multirow[b]{2}{*}{$b$} & \multirow[b]{2}{*}{ : } & \multirow[b]{2}{*}{$c$} & \multicolumn{4}{|c|}{ Distribution of phospholipid ${ }^{*}(\%)$} & \multirow{2}{*}{$\begin{array}{c}\mu \mathrm{g} \text { phospholipid } \\
\text { (mg membrane } \\
\text { protein })^{-1}\end{array}$} \\
\hline & & & & & & & & & Lyso-PE & PE & PG & DPG & \\
\hline Crude envelope & 670 & 138 & 198 & $3 \cdot 3$ & : & 0.66 & : & 1.0 & - & - & - & - & 295 \\
\hline Outer membrane & 618 & 223 & 157 & 3.86 & : & 1.43 & $:$ & 1.0 & 7 & 69 & 21 & 3 & 256 \\
\hline Inner membrane & 728 & 12 & 256 & $2 \cdot 84$ & $:$ & 0.06 & $:$ & 1.0 & 4 & 76 & 16 & 4 & 350 \\
\hline
\end{tabular}

- Expressed in terms of lipid phosphate taking total lipid phosphate content as 100. PE, phosphatidylethanolamine; PG, phosphatidylglycerol; DPG, diphosphatidylglycerol.

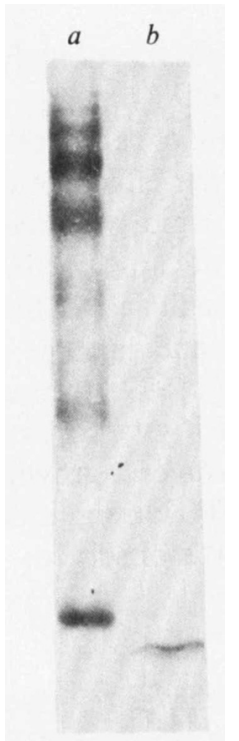

Fig. 2. LPS of $V$. cholerae. LPS was purified from cells grown in presence of $\left[{ }^{14} \mathrm{C}\right]$ acetate and examined by $14 \%(w / v)$ SDS-PAGE and autoradiography. Lanes: $a$, LPS of $V$. cholerae; $b$, phospholipids of $V$. cholerae isolated from the same culture.

\section{Outer membrane composition}

The relative proportions of proteins, phospholipids and LPS in the outer membrane of $V$. cholerae, and its phospholipid composition (Table 3 ) were similar to those reported for other Gram-negative bacteria (Lugtenberg \& van Alphen, 1983). The ratio of phospholipids to protein was similar to that reported for $E$. coli $\mathrm{K} 12$ and different from deep rough or protein-deficient mutants of E. coli and Salmonella (Koplow \& Goldfine, 1974; Smit et al., 1975). V. cholerae 569B has been reported to have smooth-type LPS (Chakrabarti \& Chatterjee, 1984; Gustafsson \& Holme, 1985) and this has also been confirmed in our laboratory. Purified LPS from cells grown in the presence of $\left[{ }^{14} \mathrm{C}\right]$ acetate showed microheterogeneity when analysed by SDS-PAGE and fluorography (Fig. 2). Such a banding pattern is characteristic of LPS molecules varying in the degree of polymerization of the O-antigenic side chain (Hitchcock et al., 1986). Furthermore, the glucosamine content of isolated lipid A was $0.26 \mu \mathrm{mol}$ (mg LPS) ${ }^{-1}$. Assuming one glucosamine disaccharide unit in lipid $\mathrm{A}$, the average molecular mass of LPS molecules of $V$. cholerae can be estimated as around $8000 \mathrm{Da}$. This agrees with the reported value of $9000 \mathrm{Da}$ for the LPS of $V$. cholerae (Gustafsson \& Holme, $1985)$ and indicates a significant contribution of O-antigenic sugars in the make-up of $V$. cholerae 569B LPS. Thus the overall composition of the outer membrane does not offer any obvious explanation of its unusual permeability to hydrophobic compounds.

$V$. cholerae was found to be highly sensitive to the antibiotic globomycin (MIC $=5 \mu \mathrm{g} \mathrm{ml}^{-1}$ ), which specifically inhibits cleavage of the signal peptide from the lipoprotein, thereby preventing its linkage with the murein sacculus of Gram-negative bacteria (Inukai et al., 1978). Within $2 \mathrm{~h}$ of globomycin treatment $\left(5 \mu \mathrm{g} \mathrm{ml}^{-1}\right)$ the viability of $V$. cholerae cells decreased by about $50 \%$ and lysis of such globomycin-treated cells suspended in $0.05 \mathrm{M}$-phosphate buffer was about $60 \%$ greater than that of control cells. These data suggest a role for mureinbound lipoprotein in maintaining the stability of the outer membrane. Preliminary studies have shown the presence of multiple species of lipoproteins in the outer membrane of $V$. cholerae.

\section{Presence of exposed phospholipids}

The high sensitivity of $V$. cholerae to hydrophobic compounds suggested domains of lipid bilayer in its outer membrane. To check this, $\left[2-{ }^{3} \mathrm{H}\right]$ glycerol-labelled cells were treated with $\mathrm{CNBr}$-activated dextran, an impermeant probe which has been used to demonstrate presence of exposed phospholipids in the outer membrane of Salmonella (Kamio \& Nikaido, 1976). Following treatment with activated dextran, phospholipids from whole cells and outer and inner membranes were isolated and the distribution of label in the various species of phospholipids was analysed quantitatively by TLC. The only significant difference in the amounts of 
Table 4. $\left[2-{ }^{3} \mathrm{H}\right]$ Glycerol-labelled phospholipids from $\mathrm{V}$. cholerae lpa-1 mutant and E. coli C-600 cells treated with CNBr-activated dextran

Treatment of $\left[2-{ }^{3} \mathrm{H}\right]$ glycerol-labelled cells $\left(2.5-4 \mathrm{mg}\right.$ dry weight, $2-3 \times 10^{6}$ c.p.m.) with CNBr-activated dextran and subsequent fractionation of control and experimental cells were done as described in Methods. The total amount of radioactivity in each sample was about $2 \times 10^{4} \mathrm{c}$.p.m. and recovery was about $84^{\circ} \%$

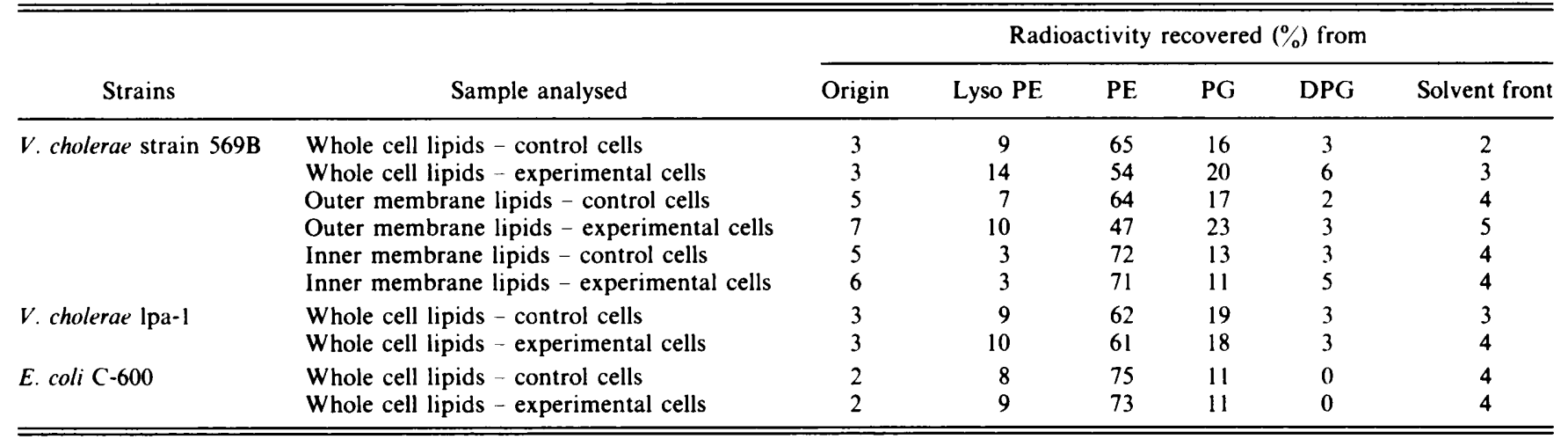

${ }^{3} \mathrm{H}$-label recovered in the different phospholipids from whole cells was a reduction in the phosphatidylethanolamine (PE)-associated radioactivity in the experimental sample (Table 4). When isolated membranes from control and experimental samples were similarly analysed, the reduction in PE-associated label was found to be strictly restricted to lipids isolated from the outer membrane of experimental cells. PE which bound to activated dextran was not extractable by solvents, presumably owing to its attachment to a large hydrophilic molecule. The ability of the probe to react selectively with exposed amino groups of PE is shown by its failure to bind PE of the inner membrane of $V$. cholerae 569B and membrane lipids (both outer and inner) of $E$. coli C-600 (Table 4). It is important to note that membrane phospholipids of the mutant strain lpa-1 which is resistant to hydrophobic compounds and detergents (Paul et al., 1990) were not labelled by CNBractivated dextran under identical conditions (Table 4). When whole cells of $V$. cholerae $569 \mathrm{~B}\left(\left[2-{ }^{3} \mathrm{H}\right] \mathrm{glycerol}\right.$ labelled) treated with activated dextran were lysed with SDS $\left(2 \% \mathrm{w} / \mathrm{v}, 2 \mathrm{~min}, 100^{\circ} \mathrm{C}\right)$ and directly spotted on TLC plates, radioactive material could be recovered from the origin. This was not seen in control cells of $V$. cholerae when analysed under identical conditions. The amount of such radioactive material was comparable to the selective decrease in $\mathrm{PE}$-associated radioactivity observed between control and experimental samples (Table 4). The origin material was eluted with water containing $2 \%(\mathrm{w} / \mathrm{v})$ SDS and after extensive dialysis hydrolysed with $\mathrm{HCl}\left(4 \mathrm{M}, 100{ }^{\circ} \mathrm{C}, 4 \mathrm{~h}\right)$ and analysed by TLC. All radioactivity present in the hydrolysate could be recovered as free glycerol, and the only ninhydrin reactive spot had the same mobility as ethanolamine.
This indicated that the radioactive material at the origin was PE-complexed with activated dextran. Similar conclusions were reached using dansyl-chloride-cyclodextrin complex which has been used to analyse the topology of phospholipids in red blood cells (SchmidtUllrich et al., 1973). When phospholipids of $V$. cholerae 569B cells treated with this probe were analysed, the PE present in the outer membrane was selectively labelled. No phospholipid of $E$. coli or $V$. cholerae lpa-1 was labelled by this probe under similar experimental conditions.

\section{Discussion}

Extensive studies have demonstrated that the hydrophobic pathway for permeation of exogenous compounds is normally non-operative in Gram-negative bacteria due to the asymmetric organization of the outer membrane (Vaara \& Nikaido, 1984). This is particularly true for species which colonize segments of intestinal tissues in the presence of bile salts and other potential noxious agents (Vaara \& Nikaido, 1984). It is only when this asymmetry is lost with appearance of phospholipids in the outer leaflet of the outer membrane that cells become permeable to hydrophobic compounds and detergents (Vaara \& Nikaido, 1984).

The fact that about $30 \%$ of the PE in the outer membrane of $V$. cholerae was accessible to exogenous CNBr-dextran (Table 4), compared to about $10 \%$ as reported in deep rough mutants of Salmonella (Kamio \& Nikaido, 1976) suggests significant phospholipid bilayers in the outer membrane of Vibrio cells. Presence of exposed phospholipids was confirmed with the use of another impermeant probe (dansyl chloride; lipid separ- 
ation by TLC; data not shown). Due to lack of adequate information on the surface area of Vibrio cells, we have not been able to estimate the number of lipid molecules in the outer membrane which could participate in bilayer formation. Phospholipid constituted about $250 \mu \mathrm{g}$ per $\mathrm{mg}$ protein in the outer membrane of $V$. cholerae (Table 3 ). This value is significantly higher than the corresponding values of 133 reported for wild-type Neisseria gonorrhoeae and 190 for that of the supersensitive env mutant derived from $N$. gonorrhoeae (Lysko \& Morse, 1981). $N$. gonorrhoeae resembles $V$. cholerae in being sensitive to hydrophobic compounds and detergents (Cannon \& Sparling, 1984). However, exogenous phospholipase $\mathrm{C}$ failed to release phospholipids from parental Neisseria cells and it was only the supersensitive env mutant whose phospholipids were accessible to phospholipase C (Lysko \& Morse, 1981). Moreover, without other supporting evidence, accessibility to phospholipase C does not necessarily indicate presence of exposed lipids in the outer membrane (Kamio \& Nikaido, 1976). Loss of structural asymmetry of the outer membrane is normally due to two kinds of defect - inability to synthesize either a major portion of the core polysaccharide moiety of LPS, or major outer-membrane proteins (Lugtenberg \& van Alphen, 1983; Vaara \& Nikaido, 1984). The relative proportion of the three major macromolecules constituting the outer membrane of $V$. cholerae (Table 3) suggest that such alterations are probably not a causative factor in the case of $V$. cholerae. The presence of murein-bound lipoprotein in $V$. cholerae outer membrane suggests that leakiness of periplasmic protein is probably not due to lack of stabilization of the outer membrane by this structural protein. The extensive blebbing of the outer membrane of $V$. cholerae 569B cells demonstrated by electron microscopy (Chatterjee \& Das, 1967) is also indicative of the unstable nature of the outer membrane.

The strain (569B) of $V$. cholerae used in this study was shown to have retained its smooth-type LPS (Chakrabarti \& Chatterjee, 1984; Gustafsson \& Holme, 1985) thereby ruling out its inadvertent conversion to a rough form due to continued growth under laboratory conditions. Incidentally, previous studies had demonstrated only two classes of LPS molecules (rough and smooth) in $V$. cholerae (Chakrabarti \& Chatterjee, 1984; Gustafsson $\&$ Holme, 1985) and the present study demonstrates microheterogeneity in its LPS structure (Fig. 2).

A significant feature of LPS molecules of $V$. cholerae 569B was their reduced net negative charge. Results presented here (Table 2) indicate that the PS moiety of LPS is primarily responsible for the low fixed negative charge of LPS molecules. The reduced content of anionic groups in the LPS molecules of $V$. cholerae compared to $E$. coli is also indicated by the binding of isolated LPS molecules with polymyxin B. The importance of inter- action of divalent cations with the proximal anionic groups in the PS moiety for stabilization of the outer membrane has been amply documented (Vaara \& Nikaido, 1984; Nikaido \& Vaara, 1985). It is conceivable that a reduced interaction of this kind could cause leakage of periplasmic enzymes as seen in $V$. cholerae. It could also be a factor in the permeation and consequent sensitivity of $V$. cholerae to hydrophilic compounds like tetracycline and neomycin (Table 1). In this context it is worth noting the dramatic changes in permeability of rough Salmonella strains with further deletion of phosphate groups from LPS (Schlecht \& Westphal, 1970).

We cannot at this stage offer a reason for the presence of phospholipid bilayers in the outer membrane of $V$. cholerae 569B. Removal of divalent cations results in increased electrostatic repulsion between neighbouring LPS molecules. This is known to result in the release of a fraction of LPS molecules and might also lead to a reorganization in the architecture of the outer membrane (Nikaido \& Vaara, 1985). Tris has been shown to render an Rc mutant of Salmonella susceptible to labelling by dansyl chloride (Schindler \& Teuber, 1978). Whether such a reorganization occurs in $V$. cholerae due to the demonstrable low content of anionic groups in its LPS, with consequent reduced binding and stabilization by divalent cations, remains to be established. A previous study which showed rapid lysis of $V$. cholerae 569B cells in the presence of EDTA and Tris (Lohia et al., 1984, 1985) emphasized the importance of divalent cations in its structural integrity.

It is difficult to visualize how $V$. cholerae 569B colonizing the small intestine would survive in such an environment when its outer membrane contains exposed phospholipids. Changes in the composition of the outer membrane due to environmental stresses are well known (Lugtenberg \& van Alphen, 1983). It would be interesting to examine the process by which the exposed phospholipids of $V$. cholerae become shielded or masked during the process of infection and colonization. The major structural change in the mutant lpa-1, which is resistant to hydrophobic compounds and does not have exposed phospholipids has been traced to defective acylation of lipid A (Paul et al., 1990). We are currently investigating the basis for the nonavailability of its outer membrane phospholipids to impermeant probes.

This work was supported by a research grant from the Department of Biotechnology, Government of India (Grant No. BT/TF/03/026/ 009/88). One of us (S. P.) is grateful to the Council of Scientific and Industrial Research for a predoctoral fellowship.

\section{References}

Cannon, J. G. \& Sparling, P. F. (1984). The genetics of Gonococcus. Annual Review of Microbiology 38, 111-133. 
Chakrabarti, D. \& Chatterjee, A. N. (1984). Studies on heterogeneous lipopolysaccharide fractions of Vibrio cholerae 569B. Journal of General Microbiology 130, 2023-2026.

ChatterJee, S. N. \& DAS, J. (1967). Electron microscopic observations on the excretion of cell wall material by Vibrio cholerae. Journal of General Microbiology 49, 1-11.

Filip, C., Fletcher, G., WulfF, J. L. \& Earhart, C. F. (1973). Solubilization of cytoplasmic membrane of $E$. coli by the ionic detergent sodium lauryl sarcosinate. Journal of Bacteriology 115 , 717-722.

GhuYsen, J. M. \& Strominger, J. L. (1963). Structure of the cell wall of Staphylococcus aureus, strain Copenhagen. 1. Preparation of fragments by enzymatic hydrolysis. Biochemistry 2, 1110-1119.

Gustafsson, B. \& Holme, T. (1985). Immunological characterization of Vibrio cholerae $0: 1$ lipopolysaccharide. $O$-side chain and core with monoclonal antibodies. Infection and Immunity 49, 275-280.

Hitchcock, P. J., Leive, L., Makela, P. H., Rietschel, E. Th., Stritmatter, W. \& Morrison, D. C. (1986). Lipopolysaccharide nomenclature - past, present and future. Journal of Bacteriology 166, 699-705.

InUKaI, M., TaKeuchi, M., Shimizu, K. \& ARal, M. (1978). Mechanism of action of globomycin. Journal of Antibiotics 31, 1203-1205

Kamio, Y. \& NiKaido, H. (1976). Accessibility of phospholipid head groups to phospholipase $C$ and cyanogen bromide activated dextran in the external medium. Biochemistry 15, 2561-2570.

Kinoshita, T., Iinuma, F. \& Tsuji, A. (1974). Fluorescent labelling of proteins and a plasma membrane using cycloheptaamylose-dansyl chloride complex. Analytical Biochemistry 61, 632-637.

Koplow, J. \& GoldFINE, H. (1974). Alterations in the outer membrane of the cell envelope of heptose-deficient mutants of Escherichia coli. Journal of Bacteriology 117, 525-542.

Lohia, A., Chatterjee, A. N. \& DAS, J. (1984). Lysis of Vibrio cholerae cells: direct isolation of the outer membrane from whole cells by treatment with urea. Journal of General Microbiology 130, 2027-2033.

Lohia, A., Majumdar, S., Chatterjee, A. N. \& Das, J. (1985). Effect of changes in the osmolarity of the growth medium on Vibrio cholerae cells. Journal of Bacteriology 163, 1158-1166.

LUGTENBERG, B. \& VAN ALPHEN, L. (1983). Molecular architecture of the outer membrane of Escherichia coli and other Gram-negative bacteria. Biochimica et Biophysica Acta 737, 51-115.

LYSKo, P. A. \& MORSE, S. A. (1981). Neisseria gonorrhoeae cell envelope: permeability to hydrophobic molecules. Journal of Bacteriology 145, 946-952.

Markwell, M. A. K., HaAs, S. M., Bieber, L. L. \& Tolbert, N. E. (1978). A modification of the Lowry procedure to simplify protein determination in the membrane and lipoprotein samples. Analytical Biochemistry 87, 206-210.

Neill, R. J., Ivins, B. E. \& Holmes, R. K. (1983). Synthesis and secretion of the plasmid-coded heat-labile enterotoxin of Escherichia coli in Vibrio cholerae. Science 221, 289-291.

Neu, C. H. \& Heppel, L. A. (1965). The release of enzymes from Escherichia coli by osmotic shock and during the formation of spheroplasts. Journal of Biological Chemistry 240, 3685-3692.
NiKaido, H. \& VAaRA, M. (1985). Molecular basis of bacterial outer membrane permeability. Microbiological Revien's 49, 1-32.

Osborn, M. J., Gander, J. E., Parisi, E. \& Carson, J. (1972). Mechanism of assembly of the outer membrane of Salmonella typhimurium. Journal of Biological Chemistry 247, 3962-3972.

Paul, S., Sen, A. K., Banerjee, N., Chatterjee, A. N. \& Das, J. (1990). Lipid A mutants of Vibrio cholerae: isolation and partial characterization. Biochemical and Biophysical Research Communications 169, 116-122.

Ray, P., Sengupta, A. \& Das, J. (1984). Phosphate repression of phage protein synthesis during infection by choleraphage $\phi 149$. Virology 136, 110-124.

Roy, N. K., Grosh, R. K. \& DAS, J. (1982). Monomeric alkaline phosphatase of Vibrio cholerae. Journal of Bacteriology 150, 1033-1039.

SCHINDLER, P. R. G. \& TEUbER, M. (1978). Ultrastructural study of Salmonella typhimurium treated with membrane active agents: specific reaction of dansyl chloride with cell envelope components. Journal of Bacteriology 135, 198-206.

SCHLECHT, S. \& WestPHAL, O. (1970). Untersuchungen zur typisierung von Salmonella-R-formen. Zentralblatt für Bakteriologie Parasitenkunde Infektionskrandheiten und Hygiene Abteilung I Originale 213, 356-381.

SChmidT-UllRich, R., K NUfermanN, H. \& Wallach, D. F. H. (1973). The reaction of 1-dimethylaminonaphthalene-5-sulfonyl chloride with erythrocyte membranes. Biochimica et Biophysica Acta 307, 353-365.

Smit, J., Kamio, Y. \& Nikaido, H. (1975). Outer membrane of Salmonella typhimurium: chemical analysis and freeze-fracture studies with lipopolysaccharide mutants. Journal of Bacteriology 124, 942-958.

Stan-Lotter, H., Gupta, M. \& Sanderson, K. E. (1979). The influence of cations on the permeability of the outer membrane of Salmonella typhimurium and other Gram-negative bacteria. Canadian Journal of Microbiology' 25, 475-485.

SUKUPOLVI, S. \& VAARA, M. (1989). Salmonella typhimurium and Escherichia coli mutants with increased outer membrane permeability to hydrophobic compounds. Biochimica et Biophysica Acta 988, 377-387

Vaara, M., Vaara, T., Jenson, M., Helander, I., Nurimen, M., Rietschel, E. Th. \& MAKela, P. M. (1981). Characterization of the lipopolysaccharide from the polymyxin-resistant pmrA mutants of Salmonella typhimurium. FEBS Letters 129, 145-149.

VAARA, M. \& NIKAIDO, H. (1984). In Handbook of Endotoxins, vol. 1, pp.1-45. Edited by E. Th. Rietschel. Amsterdam: Elsevier.

Wolf-Watz, H., Elmros, T., Normark, S. \& BloOM, G. D. (1975). Cell envelope of Neisseria gonorrhoeae: composition of penicillinsensitive and resistant strains. Infection and Immunity 11, 13321341 .

Wright, B. E. \& Rebers, P. A. (1972). Procedure for determining heptose and hexose in lipopolysaccharide: modification of the cysteine-sulphuric acid method. Analytical Biochemistry 49, 307319. 